\title{
Genome size and phenotypic variation of Nymphaea (Nymphaeaceae) species from Eastern Europe and temperate Asia
}

\author{
Magdalena Anna Dąbrowska', Kaja Rola', Polina Volkova², Jan Suda 3,4, Joanna Zalewska-Gałosz ${ }^{1 *}$ \\ 'Department of Plant Taxonomy, Phytogeography and Herbarium, Institute of Botany, Jagiellonian University, Kopernika 27, 31-501 Kraków, Poland \\ ${ }^{2}$ Department of Higher Plants, Faculty of Biology, Moscow State University, Vorobyevy Gory, 119899 Moscow, Russian Federation \\ ${ }^{3}$ Department of Botany, Faculty of Science, Charles University in Prague, Benátská 2, 12801 Prague, Czech Republic \\ ${ }^{4}$ Institute of Botany, The Czech Academy of Sciences, Zámek 1, 25243 Průhonice, (zech Republic
}

\section{Abstract}

Despite long-term research, the aquatic genus Nymphaea still possesses major taxonomic challenges. High phenotypic plasticity and possible interspecific hybridization often make it impossible to identify individual specimens. The main aim of this study was to assess phenotypic variation in Nymphaea taxa sampled over a wide area of Eastern Europe and temperate Asia. Samples were identified based on species-specific genome sizes and diagnostic morphological characters for each taxon were then selected. A total of 353 specimens from 32 populations in Poland, Russia and Ukraine were studied, with nine biometric traits being examined. Although some specimens morphologically matched $N$. xborealis (a hybrid between $N$. alba and N. candida) according to published determination keys, only one hybrid individual was revealed based on genome size data. Other specimens with intermediate morphology possessed genome size corresponding to N. alba, $N$. candida or N. tetragona. This indicates that natural hybridization between N. alba and N. candida is not as frequent as previously suggested. Our results also revealed a considerably higher variation in the studied morphological traits (especially the quantitative ones) in N. alba and N. candida than reported in the literature. A determination key for the investigated Nymphaea species is provided, based on taxonomically-informative morphological characters identified in our study.

Keywords: Nymphaea alba; Nymphaea candida; Nymphaea tetragona; Nymphaea ×borealis; morphometric analysis; flow cytometry; genome size; interspecific hybridization

\section{Introduction}

The Nymphaeaceae is a family of hydrophytes that occur in water reservoirs worldwide. Nymphaea L. (water lily) is one of the six genera belonging to the Nymphaeaceae. Approximately 50 representatives of the genus are known [1]. Several varieties, chromosome races and hybrids have been reported for many of them [2].

This study focuses on four taxa of Nymphaea that belong to the Eurasian Nymphaea clade [3], namely: N. alba L., N. candida J. Presl, N. tetragona Georgi, and N. $\times$ borealis Camus, the hybrid between N. alba and N. candida. Each of three aforementioned species has its well-defined distribution range [4]. Nymphaea alba occurs almost throughout Europe with the exception of northern areas and a considerable part of the Iberian Peninsula, and also in the Caucasus, western part of Asia and North Africa [5-7]. Nymphaea candida is a Euro-Siberian species with the center of its occurrence in

*Corresponding author. Email: joanna.zalewska-galosz@uj.edu.pl Handling Editor: Krzysztof Spalik northern, central and eastern parts of Europe, from where it extends up to western Siberia and central Asia. The species reaches the southern limit of its continuous range in Poland [5-7]. Nymphaea tetragona occurs in northern and eastern parts of the Scandinavian Peninsula, northern and eastern parts of Asia, northern part of India and in North America $[5,8]$. All three species also differ by habitat preferences. Representatives of N. alba occur in meso- and eutrophic waters, with a $\mathrm{pH}$ reaction ranging from weakly acidic to alkaline ( $\mathrm{pH}$ 5.5-8.3) whereas $N$. candida prefers poorer, meso- and oligotrophic waters, with a $\mathrm{pH}$ ranging from weakly acidic to neutral (pH 5.5-7.1) $[9,10]$. Although N. alba often forms phytocoenoses in eutrophic waters and $N$. candida grows better in more nutrient-poor waters, with a narrower range of requirements [11], ecological requirements of both species overlap and they can be found in both aquatic habitat types [11,12]. Nymphaea tetragona is found in lakes, river backwaters and small oxbow lakes in thickets and silty bottom in the lowland and montane zones [5].

All three Nymphaea species are closely related [8]. They have similar morphological traits and their distribution ranges overlap to some extent. Taxonomically informative 
characters include the number of stigma rays, stigma color, the shape of inner filaments, the size of the flower and pollen sculpture [9,10,13-20]. However, individuals cannot always be identified using these characters, especially when a specimen presents some transitional characters or even a combination of diagnostic characters of different taxa. It may be especially difficult to determine species in areas where distribution ranges of $N$. alba and N. candida overlap and the hybrid $N . \times$ borealis can be formed [21,22].

Nymphaea $\times$ borealis has just been noted in the XIXth century [21] and it is included in many determination keys of vascular plants [9,10,14-17]. Over the time, the hybrid has been reported from several geographic regions $[12,13,23,24]$. On the other hand, some authors, bearing in mind a great plasticity of $N$. alba and N. candida, refrain from identification of $N . \times$ borealis and report only Nymphaea sp. [25] or "intermediate forms" [26,27] to avoid incorrect determination. Based on morphological and biological investigations of $N$. $\times$ borealis to date, its morphological traits are a combination of traits characteristic for both parental species $[13,20,26,27]$. The hybrid is also characterized by decreased pollen production and lower fertility $[28,29]$. Although the hybridization between N. alba and N. candida was convincingly confirmed by genetic studies $[18,20]$, the majority of $N$. $\times$ borealis records is solely based on morphological identification. Recently published cytogenetic studies of Nymphaea taxa conducted in the Czech Republic [20] proved that only $1.8 \%$ of investigated specimens represented $N$. $\times$ borealis. This result is incongruent with previous reports on extensive hybridization between N. alba and N. candida [24].

In front of the controversial delimitation of Nymphaea taxa due to their high phenotypic plasticity and vague determination of hybrids [30], we performed a detailed study of morphological variation of N. alba, N. candida, their putative hybrid $N$. $\times$ borealis, and N. tetragona, sampled over a wide area of Eastern Europe and temperate Asia. Specifically, our aims were: $(\boldsymbol{i})$ to identify the sampled specimens based on morphological characters provided in the published determination keys (a subjective identification); (ii) to delimit the taxonomic categories based on differences in relative genome size estimated by DNA flow cytometry (an objective identification), (iii) to compare the results of both approaches and discuss potential sources of incongruence, $(\boldsymbol{i} v)$ to assess the frequency of the interspecific hybrid $N$. $\times$ borealis, based on intermediate genome size values, and finally $(\boldsymbol{v})$ to select morphological traits having the greatest discrimination power in morphometric analyses and therefore presenting the highest taxonomic value.

\section{Material and methods}

\section{Morphometric analysis}

In total, 353 specimens from 32 localities in Poland, Russia and Ukraine (Tab. 1, Fig. 1) were included in the study. Depending on a population size two to thirty one individuals per population were studied. Nine traits, including four quantitative and five qualitative (Tab. 2), were scored or measured directly in the field on randomly chosen individuals. One randomly chosen part of plant (e.g. outer stamen, stigma, leaf etc.) per each investigated individual was measured. Measurements were conducted on fresh plants because some parameters, including length of outer petals, leaf length and maximum leaf width, can change after dehydration. In the field, analyzed individuals were tentatively ascribed to N. alba, N. candida, N. ×borealis and N. tetragona using morphological characters indicated in the published determination keys $[5,13,14,17,19,20,24,26,27,31,32]$ (also Volkova unpublished).

\section{Flow cytometry}

Relative genome size was estimated for all morphologically investigated samples using DNA flow cytometry (FCM). Measurements were performed using a Partec PA II instrument (Partec GmbH., Münster, Germany) equipped with a mercury arc lamp for UV excitation. Silica-dried leaf samples were analyzed using Otto buffers [33], as described by Suda and Trávníček [34]. Intact nuclei were isolated by tissue chopping in Otto I buffer $(0.1 \mathrm{M}$ citric acid, $0.5 \%$ Tween 20), and the nuclear suspension was stained using Otto II buffer $\left(0.4 \mathrm{Na}_{2} \mathrm{HPO}_{4} \times 12 \mathrm{H}_{2} \mathrm{O}\right)$ supplemented with AT-selective fluorochrome DAPI (at final concentration $4 \mu \mathrm{g} / \mathrm{ml})$ and $\beta$-mercaptoethanol $(2 \mu \mathrm{l} / \mathrm{ml})$. Lycopersicon esculentum Mill. cv. Stupické polní rané, 2C $=1.96$ pg [35] was used as an internal reference standard. Flow histograms were evaluated using the Partec FloMax software ver. 2.4d.

\section{Statistical analyses}

Before statistical analyses each specimen was ascribed to a particular taxon based on estimated relative genome size values. It has been shown previously that all four taxa under study have distinct sizes of holoploid genome, allowing their reliable identification $[8,20]$.

Each a priori determined specimen was treated as an operational taxonomic unit (OTU) in accordance with the methods used in numerical taxonomy [36]. Prior to the statistical analyses, the distribution normality of quantitative variables was verified using the Lilliefors test. For multivariate analyses the data were standardized to avoid the effect of differences between measurement scales.

Principal component analysis (PCA) was conducted using all quantitative characters, based on the correlation matrix [37]. The analysis was performed in order to get insight into the overall pattern of phenotypic variation. The analysis yielded a reduced set of variables (traits), which were most strongly correlated with the principal components. Factors were chosen according to the scree test [38]. Principal coordinate analysis (PCoA) performed with Gower's similarity coefficient [39] was also used to assess morphological differentiation of the taxa. All quantitative and qualitative characters were included in PCoA.

After using Levene's test to assess the equality of variance, one-way analysis of variance (ANOVA) followed by the Tukey's HSD test for unequal sample frequencies was conducted to assess interspecific differences between means of quantitative characters.

Standard discriminant analyses were used to determine which characters best discriminate the studied species and to check the correctness of specimens' assignment into particular species defined on the basis of sizes of holoploid genome. 
Tab. 1 Nymphaea populations investigated in our study.

\begin{tabular}{|c|c|c|c|c|c|c|c|}
\hline $\begin{array}{c}\text { No. in } \\
\text { distribution } \\
\text { map }\end{array}$ & $\begin{array}{l}\text { Pop. } \\
\text { number }\end{array}$ & Region & Locality & Geographic coordinates & Taxon $_{\text {MORPH }}$ & Taxon $_{F C M}$ & $\begin{array}{l}\text { No. of } \\
\text { individuals } \\
\text { studied per } \\
\text { population }\end{array}$ \\
\hline \multirow[t]{15}{*}{1} & 101 & \multirow{15}{*}{$\begin{array}{l}\text { Warmia- } \\
\text { Masuria } \\
\text { Province, } \\
\text { Poland }\end{array}$} & Lake Dadaj & N $53^{\circ} 53^{\prime} 21^{\prime \prime}$ E $20^{\circ} 52^{\prime} 15^{\prime \prime}$ & N. $\times$ borealis & N. alba & 14 \\
\hline & 102 & & Lake Kierzlińskie & N $53^{\circ} 48^{\prime} 19^{\prime \prime}$ E $20^{\circ} 44^{\prime} 27^{\prime \prime}$ & N. $\times$ borealis & N. candida & 15 \\
\hline & 103 & & Lake Klimunt & $\mathrm{N} 53^{\circ} 42^{\prime} 30^{\prime \prime}$ E $21^{\circ} 27^{\prime} 2^{\prime \prime}$ & N. alba & N. alba & 8 \\
\hline & 104 & & $\begin{array}{l}\text { unnamed lake near } \\
\text { town Purda }\end{array}$ & N $53^{\circ} 42^{\prime} 11^{\prime \prime}$ E $20^{\circ} 43^{\prime} 35^{\prime \prime}$ & N. $\times$ borealis & N. candida & 30 \\
\hline & 105 & & Lake Kołowinek & N $53^{\circ} 44^{\prime} 25^{\prime \prime}$ E $21^{\circ} 25^{\prime} 43^{\prime \prime}$ & N. $\times$ borealis & N. candida & 10 \\
\hline & 106 & & Lake Leleskie & N $53^{\circ} 39^{\prime} 24^{\prime \prime}$ E $20^{\circ} 49^{\prime} 34^{\prime \prime}$ & N. alba & N. alba & 16 \\
\hline & 107 & & Lake Lisunie Duże & N $53^{\circ} 46^{\prime} 49^{\prime \prime}$ E $21^{\circ} 30^{\prime} 24^{\prime \prime}$ & N. alba & N. alba & 9 \\
\hline & 108 & & Lake Majcz Mały & $\mathrm{N} 53^{\circ} 45^{\prime} 56^{\prime \prime} \mathrm{E} 21^{\circ} 26^{\prime} 20^{\prime \prime}$ & N. alba & N. alba & 3 \\
\hline & 109 & & Lake Warnołty & $\mathrm{N} 53^{\circ} 43^{\prime} 8^{\prime \prime}$ E $21^{\circ} 37^{\prime} 33^{\prime \prime}$ & N. $\times$ borealis & N. candida & 14 \\
\hline & 110 & & Lake Warnołty (NE bay) & N $53^{\circ} 43^{\prime} 43^{\prime \prime}$ E $21^{\circ} 38^{\prime} 49^{\prime \prime}$ & N. alba & N. alba & 5 \\
\hline & & & & & & N. $\times$ borealis & 1 \\
\hline & & & & & & N. candida & 1 \\
\hline & 111 & & Lake Wierzbowskie & N $53^{\circ} 50^{\prime} 14^{\prime \prime}$ E $21^{\circ} 19^{\prime} 25^{\prime \prime}$ & N. alba & N. alba & 29 \\
\hline & 112 & & Lake Wygryny & N $53^{\circ} 40^{\prime} 39^{\prime \prime}$ E $21^{\circ} 32^{\prime} 39^{\prime \prime}$ & N. alba & N. alba & 8 \\
\hline & 113 & & $\begin{array}{l}\text { Lake Zgniłek, near city } \\
\text { Olsztyn }\end{array}$ & N $53^{\circ} 47^{\prime} 25^{\prime \prime}$ E $20^{\circ} 24^{\prime} 14^{\prime \prime}$ & N. $\times$ borealis & N. candida & 31 \\
\hline \multirow[t]{5}{*}{2} & 701 & \multirow{5}{*}{$\begin{array}{l}\text { Kiev } \\
\text { Region, } \\
\text { Ukraine }\end{array}$} & River Kozinka & $\mathrm{N} 48^{\circ} 40^{\prime} 0^{\prime \prime}$ E $34^{\circ} 17^{\prime} 59^{\prime \prime}$ & N. alba & N. alba & 5 \\
\hline & 702 & & River Dnepr & $\mathrm{N} 50^{\circ} 23^{\prime} 59^{\prime \prime}$ E $30^{\circ} 30^{\prime} 0^{\prime \prime}$ & N. candida & N. candida & 4 \\
\hline & 703 & & River Dnepr & $\mathrm{N} 48^{\circ} 30^{\prime}$ E $34^{\circ} 17^{\prime}$ & N. alba & N. alba & 4 \\
\hline & 704 & & River Dnepr & $\mathrm{N} 48^{\circ} 30^{\prime}$ E $34^{\circ} 17^{\prime}$ & N. alba & N. alba & 4 \\
\hline & 705 & & River Dnepr & $\mathrm{N} 48^{\circ} 30^{\prime}$ E $34^{\circ} 17^{\prime}$ & N. alba & N. alba & 3 \\
\hline \multirow[t]{3}{*}{3} & 708 & \multirow{3}{*}{$\begin{array}{l}\text { Tver' } \\
\text { Region, } \\
\text { Russia }\end{array}$} & River Kagra & N $57^{\circ} 53^{\prime} 59^{\prime \prime}$ E $35^{\circ} 23^{\prime} 59^{\prime \prime}$ & N. candida & N. candida & 2 \\
\hline & 709 & & Lake Glukhoe & N $57^{\circ} 53^{\prime} 59^{\prime \prime}$ E $35^{\circ} 0^{\prime} 0^{\prime \prime}$ & N. candida & N. candida & 5 \\
\hline & 710 & & River Volchna & N $57^{\circ} 53^{\prime} 59^{\prime \prime}$ E $34^{\circ} 36^{\prime} 5^{\prime \prime}$ & N. alba & N. alba & 5 \\
\hline \multirow[t]{3}{*}{4} & 723 & \multirow{3}{*}{$\begin{array}{l}\text { Karelia } \\
\text { Republic, } \\
\text { Russia }\end{array}$} & Lake Kamennoe & $\mathrm{N} 64^{\circ} 42^{\prime}$ E $30^{\circ} 48^{\prime}$ & N. candida & N. candida & 5 \\
\hline & 724 & & unnamed lake 1 & $\mathrm{~N} 64^{\circ} 42^{\prime}$ E $30^{\circ} 48^{\prime}$ & N. candida & N. candida & 4 \\
\hline & 725 & & unnamed lake 2 & $\mathrm{~N} 64^{\circ} 42^{\prime}$ E $30^{\circ} 48^{\prime}$ & N. candida & N. candida & 4 \\
\hline \multirow[t]{6}{*}{5} & 716 & \multirow{6}{*}{$\begin{array}{l}\text { Chelyabink } \\
\text { Region, } \\
\text { Russia }\end{array}$} & Lake Bol'shoje & $\mathrm{N} 55^{\circ} 6^{\prime} \mathrm{E} 60^{\circ} 23^{\prime}$ & N. candida & N. candida & 4 \\
\hline & 717 & & $\begin{array}{l}\text { Miassovoe } \\
\text { Lake Bol'shoje } \\
\text { Miassovoe }\end{array}$ & $\mathrm{N} 55^{\circ} 6^{\prime} \mathrm{E} 60^{\circ} 23^{\prime}$ & N. candida & N. candida & 5 \\
\hline & 718 & & Lake Maloje Miassovoe & $\mathrm{N} 55^{\circ} 6^{\prime} \mathrm{E} 60^{\circ} 23^{\prime}$ & N. alba & N. alba & 5 \\
\hline & 719 & & $\begin{array}{l}\text { Lake Bol'shoje } \\
\text { Miassovoe }\end{array}$ & $\mathrm{N} 55^{\circ} 6^{\prime} \mathrm{E} 60^{\circ} 23^{\prime}$ & N. candida & N. candida & 5 \\
\hline & 720 & & $\begin{array}{l}\text { Lake Bol'shoje } \\
\text { Miassovoe }\end{array}$ & $\mathrm{N} 55^{\circ} 6^{\prime} \mathrm{E} 60^{\circ} 23^{\prime}$ & N. candida & N. candida & 4 \\
\hline & 721 & & Lake Argayash & $\mathrm{N} 55^{\circ} 30^{\prime} 0^{\prime \prime}$ E $60^{\circ} 53^{\prime} 59^{\prime \prime}$ & N. candida & N. candida & 5 \\
\hline \multirow[t]{5}{*}{6} & 711 & \multirow{5}{*}{$\begin{array}{l}\text { Khanty- } \\
\text { Mansijskij } \\
\text { AO, Russia }\end{array}$} & Lake Aran-Tur & $\mathrm{N} 59^{\circ} 53^{\prime} \mathrm{E} 64^{\circ} 47^{\prime}$ & N. tetragona & N. tetragona & 9 \\
\hline & 712 & & Lake Aran-Tur & $\mathrm{N} 59^{\circ} 53^{\prime} \mathrm{E} 64^{\circ} 47^{\prime}$ & N. candida & N. candida & 6 \\
\hline & 713 & & River Akh & $\mathrm{N} 59^{\circ} 53^{\prime} \mathrm{E} 64^{\circ} 47^{\prime}$ & N. tetragona & N. tetragona & 9 \\
\hline & 714 & & Lake Alas & $\mathrm{N} 59^{\circ} 53^{\prime} \mathrm{E} 64^{\circ} 47^{\prime}$ & N. candida & N. candida & 8 \\
\hline & 715 & & Lake Lopukhovoe & $\mathrm{N} 59^{\circ} 53^{\prime} \mathrm{E} 64^{\circ} 47^{\prime}$ & N. candida & N. candida & 4 \\
\hline
\end{tabular}


Tab. 1 (continued)

\begin{tabular}{|c|c|c|c|c|c|c|c|}
\hline $\begin{array}{c}\text { No. in } \\
\text { distribution } \\
\text { map }\end{array}$ & $\begin{array}{c}\text { Pop. } \\
\text { number }\end{array}$ & Region & Locality & Geographic coordinates & Taxon $_{\text {MORPH }}$ & Taxon $_{\mathrm{FCM}}$ & $\begin{array}{c}\text { No. of } \\
\text { individuals } \\
\text { studied per } \\
\text { population }\end{array}$ \\
\hline \multirow[t]{9}{*}{7} & 730 & \multirow{9}{*}{$\begin{array}{l}\text { Amur } \\
\text { Region, } \\
\text { Russia }\end{array}$} & $\begin{array}{l}\text { unnamed lake near } \\
\text { town Arkhara }\end{array}$ & $\mathrm{N} 49^{\circ} 23^{\prime} 59^{\prime \prime}$ E $130^{\circ} 5^{\prime} 59^{\prime \prime}$ & N. tetragona & N. tetragona & 5 \\
\hline & 732 & & Lake Krivoe & $\mathrm{N} 48^{\circ} 53^{\prime} 59^{\prime \prime} \mathrm{E} 130^{\circ} 24^{\prime} 2^{\prime \prime}$ & N. tetragona & N. tetragona & 5 \\
\hline & 733 & & Lake Glubokoje & $\mathrm{N} 48^{\circ} 53^{\prime} 59^{\prime \prime} \mathrm{E} 130^{\circ} 11^{\prime} 59^{\prime \prime}$ & N. tetragona & N. tetragona & 5 \\
\hline & 734 & & $\begin{array}{l}\text { Lake Bol'shoje } \\
\text { Pereshjejechnoje }\end{array}$ & $\mathrm{N} 49^{\circ} 23^{\prime} 59^{\prime \prime}$ E $130^{\circ} 5^{\prime} 59^{\prime \prime}$ & N. tetragona & N. tetragona & 4 \\
\hline & 735 & & Lake Dolgoe & $\mathrm{N} 48^{\circ} 53^{\prime} 59^{\prime \prime} \mathrm{E} 130^{\circ} 11^{\prime} 59^{\prime \prime}$ & N. tetragona & N. tetragona & 4 \\
\hline & 736 & & Lake Kljoshinkoje & N $50^{\circ} 0^{\prime} 0^{\prime \prime}$ E $129^{\circ} 11^{\prime} 59^{\prime \prime}$ & N. tetragona & N. tetragona & 5 \\
\hline & 737 & & Lake Krivoe & $\mathrm{N} 48^{\circ} 53^{\prime} \mathrm{E} 130^{\circ} 24^{\prime}$ & N. tetragona & N. tetragona & 5 \\
\hline & 738 & & Lake Krivoe & $\mathrm{N} 48^{\circ} 53^{\prime} \mathrm{E} 130^{\circ} 24^{\prime}$ & N. tetragona & N. tetragona & 5 \\
\hline & 739 & & Lake Krivoe & N $49^{\circ} 53^{\prime} 59^{\prime \prime}$ E $129^{\circ} 35^{\prime} 59^{\prime \prime}$ & N. tetragona & N. tetragona & 5 \\
\hline 8 & 740 & $\begin{array}{l}\text { Primorskij } \\
\text { Kraj, Russia }\end{array}$ & Lake Mramornoje & $\mathrm{N} 42^{\circ} 36^{\prime} 5^{\prime \prime}$ E $130^{\circ} 48^{\prime} 4^{\prime \prime}$ & N. tetragona & N. tetragona & 7 \\
\hline
\end{tabular}

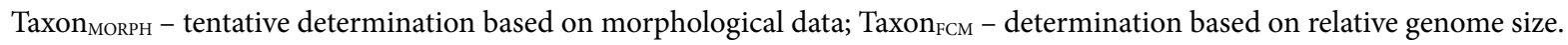

The matrix of quantitative traits was subjected to a forward stepwise analysis. Discriminatory power was expressed by the Wilks' lambda statistic. Classificatory discriminant analysis was then applied to classify the samples [40]. This procedure yields the percentage of correctly classified individuals into the a priori set taxonomic categories (i.e. Nymphaea species delimited based on genome size values). For data analyses and statistical calculations STATISTICA 9.1 and MVSP 3.2 were used [41].

Based on different multivariate statistical analyses a determination key for the investigated species was prepared. The values represent $10 \%$ and $90 \%$ percentiles, and the values in parentheses are minima and maxima. Nymphaea $\times$ borealis was not included due to the low number of samples (only a single specimen was ascribed to this nothotaxon based on genome size data).

\section{Results}

FCM analyses revealed four non-overlapping groups of relative genome sizes, corresponding to individual $\mathrm{Nym}$ phaea taxa. Nymphaea alba, N. candida, N. tetragona and $N$. $\times$ borealis were recorded at 14, 19, 12 and one locality, respectively. Mean relative fluorescence intensities $\pm S D$ and ranges of variation (setting fluorescence intensity of

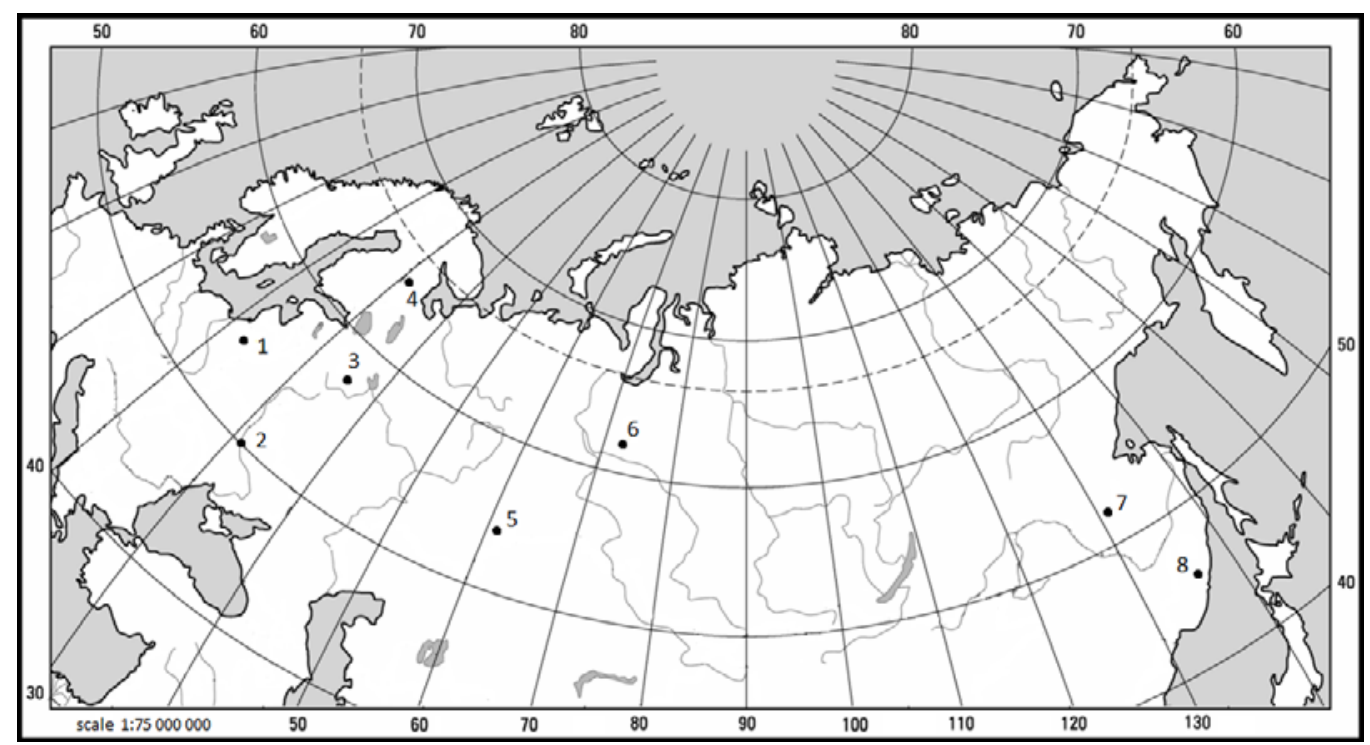

Fig. 1 Map with the localities of investigated Nymphaea populations. Numbers correspond with populations described in Tab. 1. 
Tab. 2 List of quantitative and qualitative characters measured and scored in morphometric analysis. Description, corresponding abbreviation and a measure unit or scale are given for each character.

\begin{tabular}{llll}
\hline No. & Character & Abb. & Unit/Scale \\
\cline { 2 - 3 } 1 & Length of outer petals & LoOP & $\mathrm{mm}$ \\
2 & Leaf length (from tip to leaf lobe) & LL & $\mathrm{mm}$ \\
3 & Maximum leaf width & MLW & $\mathrm{mm}$ \\
4 & Number of stigma rays & NoSR & discrete cardinal \\
5 & Shape of inner stamen filament & SoISF & $1=$ linear; $2=$ lanceolate; $3=$ round \\
6 & Stigma color & SC & $1=$ yellow; $2=$ yellow-orange; $3=$ orange; $4=$ red \\
7 & Shape of central stigma projection & SoCSP & $1=$ short hemispherical; $2=$ long conical \\
8 & Cup base shape & CS & $1=$ round; $2=$ tetrahedral; $3=$ tetrahedral with a rib \\
9 & Shape of the leaf vein leading to the lobe tip & SoMLV & $\begin{array}{l}1=\text { straight, } 2=\text { bent in the first third of its length; } 3=\text { bent } \\
\text { along its entire length }\end{array}$ \\
\hline
\end{tabular}

Lycopersicon esculentum as unit value) were as follows: N. alba $(N=118) 1.858 \pm 0.051(1.701-1.951) ; N$. candida $(N=166) 2.608 \pm 0.104(2.407-2.917) ; N$. tetragona $(N=$ 68) $0.811 \pm 0.015(0.776-0.862)$ and $N$. $\times$ borealis $(N=1)$ 2.214 (Fig. 2). The coefficient of variation (CV) of G0/G1 fluorescence peaks of Nymphaea samples did not exceed the arbitrary threshold of $5 \%$. The taxa were clearly separated; the mean fluorescence value of $N$. candida almost equaled the sum of corresponding values of $N$. alba and N. tetragona. The value of $N$. $\times$ borealis fall midway between the means for $N$. alba and N. candida. All individuals identified initially as $N$. $\times$ borealis using morphological characters turned out to be either $N$. alba (14 individuals from one population) or N. candida (100 individuals from five populations; see Tab. 1). The only cytometrically-confirmed individual of $N$. $\times$ borealis originated from the locality where both putative parents were also recorded.

Four quantitative characters with the highest factor loadings on the first principal component $(r>0.60)$ were detected in PCA. The first two components accounted for $93.33 \%$ of total variance (Tab. 3). The first axis explained $82.95 \%$ of

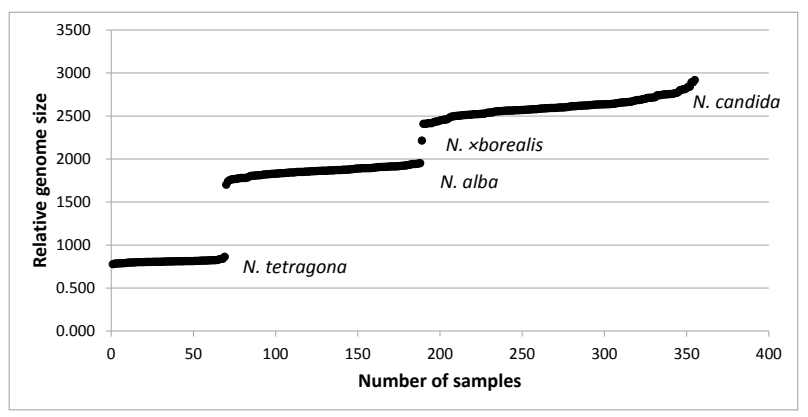

Fig. 2 Scatterplot of relative genome sizes of 353 individuals of water lilies as estimated by DAPI flow cytometry. Four nonoverlapping groups were detected, corresponding to $N$. alba (118 specimens), N. candida (166 specimens), N. tetragona (68 specimens) and $N . \times$ borealis (one specimen). Internal reference standard (Lycopersicon esculentum cv. Stupické polní rané, $2 \mathrm{C}=$ $1.96 \mathrm{pg}$ ) was given as unit of fluorescence. the variation and the second axis $10.39 \%$. The four groups representing particular taxa were not clearly separated on the scatterplot (Fig. 3) and the specimens expressed a rather continuous range of morphological variation regardless of their taxonomic identity. The first PCA axis was most highly influenced by: leaf length, maximum leaf width and length of outer petals (Fig. 4) while the number of stigma rays was most strongly correlated with the second PCA axis.

Variability ranges of quantitative characters for particular taxa are presented in Tab. 4 . The results of the one-way ANOVA revealed significant $(P<0.001)$ differences in all quantitative characters. Values of $F$-statistics obtained from ANOVA are given in Tab. 4. The most important quantitative traits were: length of outer petals, number of stigma rays and maximum leaf width.

The variation of qualitative characters for each taxon is shown in Fig. 5. Linear filaments of inner stamens were most frequently recorded in N. alba (97.5\% of individuals), whereas filaments were usually lanceolate $(86.7 \%)$ or rarely linear (13.3\%) in N. candida. Nymphaea tetragona is characterized by a lanceolate $(48.5 \%)$ or round $(51.5 \%)$

Tab. 3 Results of the principal component analysis (PCA) - eigenvalues, cumulative variance and factor loadings for the four quantitative characters.

\begin{tabular}{lcc}
\hline & \multicolumn{2}{c}{ Factor loadings } \\
\cline { 2 - 3 } Character & \multicolumn{1}{c}{$\mathbf{2}$} \\
\hline LoOP & $\mathbf{- 0 . 9 1}$ & -0.08 \\
LL & $\mathbf{- 0 . 9 4}$ & -0.21 \\
MLW & $\mathbf{- 0 . 9 6}$ & -0.20 \\
NoSR & $\mathbf{- 0 . 8 2}$ & 0.57 \\
Eigenvalue & 3.32 & 0.42 \\
Cumulative variance (\%) & 82.95 & 93.33 \\
\hline
\end{tabular}

The highest $(>0.60)$ values of factor loadings are given in bold. See Tab. 2 for character abbreviations. 


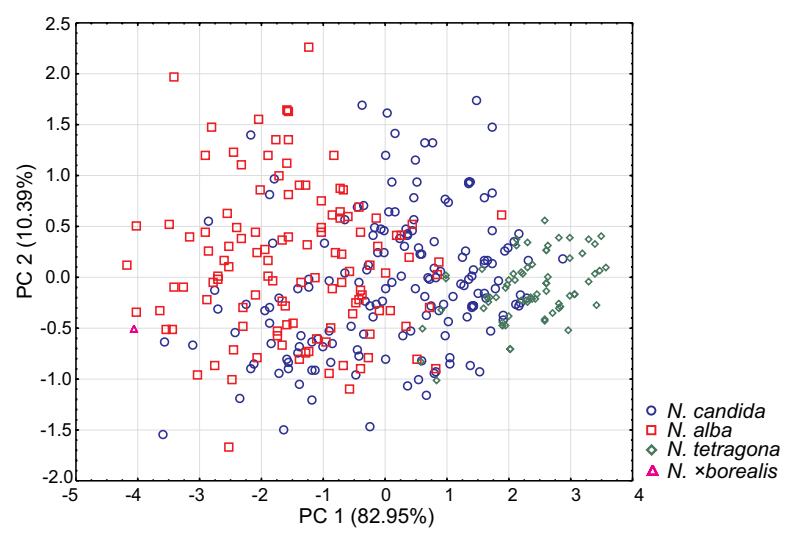

Fig. 3 Scatterplot presenting the result of principal component analysis (PCA) of samples representing N. candida, N. alba, $N$. tetragona and $N$. $\times$ borealis delimited based on distinct genome sizes.

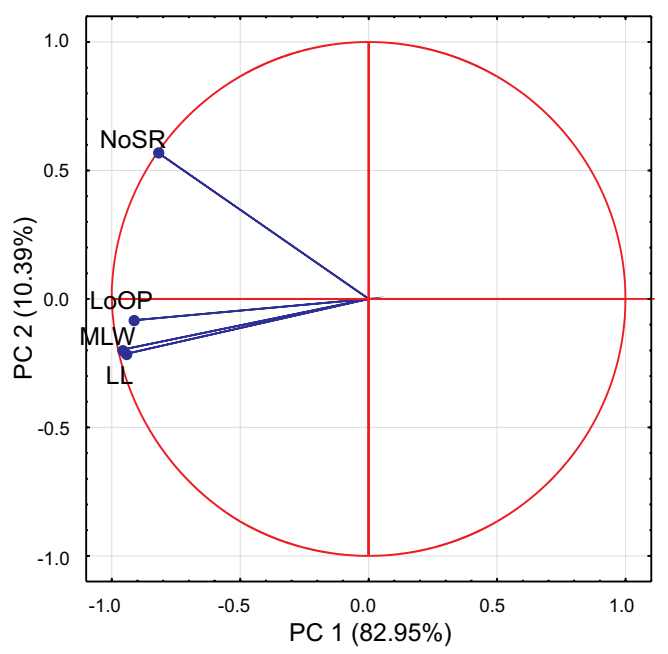

Fig. 4 Chart presenting factor loadings of principal component analysis (PCA). Abbreviations of characters are shown in Tab. 2.

stamen filaments. The stigma was most commonly yellow in N. alba and N. candida ( $85.6 \%$ and $50.6 \%$, respectively). In those individuals of $N$. alba which had not yellow stigma it was either yellow-orange $(8.5 \%)$, orange $(5.1 \%)$ or red

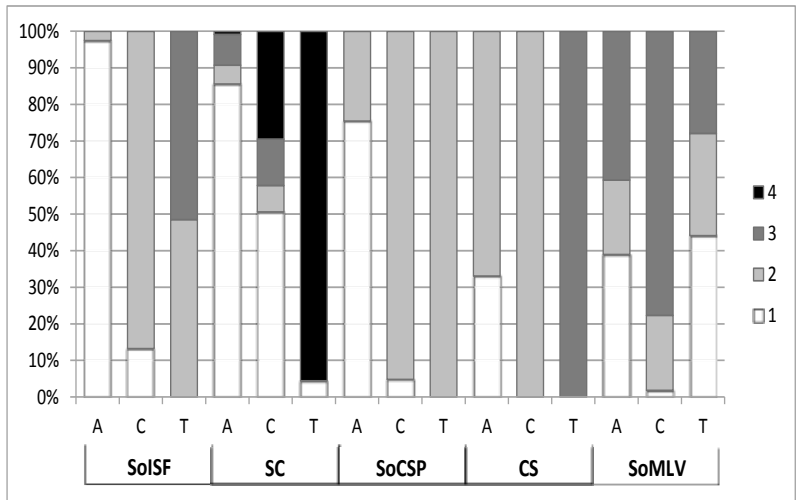

Fig. 5 Frequencies of particular qualitative characters in examined species. The explanation of particular values $(1,2,3,4)$ and character abbreviations are shown in Tab. 2. A - N. alba; C - N. candida; $\mathrm{T}-\mathrm{N}$. tetragona.

$(0.8 \%)$. In the case of $N$. candida the remaining individuals had stigmas red (29.5\%), orange $(12.7 \%)$ or yellow-orange (7.2\%). Red stigma was observed in nearly all specimens of N. tetragona (95.6\%), while remaining $4.4 \%$ of specimens had yellow stigma. A short, hemispherical central stigma projection was noted in $75.4 \%$ of individuals representing N. alba whereas it was mostly long and conical in the vast majority of N. candida (95.2\%) and N. tetragona (100\%) samples. A tetrahedrally-shaped cup base was observed in all specimens of $N$. candida. Similarly, all $N$. tetragona individuals had a cup base which was tetrahedrally-shaped with a prominent rib. It was round-shaped in only $33.1 \%$ plants of N. alba. The leaf vein leading to the lobe tip was bent along its length in the majority of $N$. candida specimens $(77.7 \%)$ while it was straight in $44.1 \%$ of $N$. tetragona specimens. For $N$. alba this character was completely uninformative. In $40.7 \%$ of N. alba individuals the vein was bent, in $20.3 \%$ it was bent in the first third of its length and in $39.0 \%$ cases it was straight. The only $N$. $\times$ borealis specimen detected in this study had respectively: lanceolate stamen filaments, yellow stigma, a short, hemispherical central stigma projection, tetrahedral cup base and the leaf vein leading to the lobe tip bent along its entire length.

Tab. 4 Descriptive statistics of the four quantitative characters for each Nymphaea species.

\begin{tabular}{|c|c|c|c|c|c|c|c|}
\hline \multirow{3}{*}{$\begin{array}{l}\text { Number of } \\
\text { individuals }\end{array}$} & \multicolumn{2}{|c|}{ Nymphaea candida } & \multicolumn{2}{|c|}{ Nymphaea alba } & \multicolumn{2}{|c|}{ Nymphaea tetragona } & \multirow[b]{3}{*}{$F$ value; $P$ value } \\
\hline & \multicolumn{2}{|c|}{165} & \multicolumn{2}{|c|}{118} & \multicolumn{2}{|c|}{68} & \\
\hline & $M \pm S D$ & Min-Max & $M \pm S D$ & Min-Max & $M \pm S D$ & $\operatorname{Min}-\mathbf{M a x}$ & \\
\hline LoOP & $44.7 \pm 13.3$ & $26.0-81.5$ & $58.3 \pm 11.2$ & $32.5-80.5$ & $22.8 \pm 5.2$ & $11.0-35.0$ & 206.22; $P<0.001$ \\
\hline LL & $122.8 \pm 37.5$ & $33.0-230.0$ & $155.9 \pm 33.6$ & $66.0-280.0$ & $76.7 \pm 23.3$ & $25.0-138.0$ & 115.85; $P<0.001$ \\
\hline MLW & $185.1 \pm 58.0$ & $77.0-345.0$ & $238.2 \pm 48.1$ & $104.0-344.0$ & $109.4 \pm 31.3$ & $42.0-190.0$ & 139.58; $P<0.001$ \\
\hline NoSR & $11.8 \pm 2.5$ & $7.0-20.0$ & $14.8 \pm 2.5$ & $8.0-23.0$ & $8.3 \pm 1.1$ & $6.0-11.0$ & 149.42; $P<0.001$ \\
\hline
\end{tabular}

Results of one-way analysis of variance - ANOVA $(P<0.001): F$ and $P$ values for characters with normal distribution; Results of Kruskal-Wallis test $(P<0.001): F$ and $P$ values for characters with non-normal distribution. See Tab. 2 for character abbreviations. $M$ - arithmetical mean; $S D$ - standard deviation; Min - minimum value; Max - maximum value. 
Discriminant analysis (DA) confirmed the diagnostic value of two quantitative characters indicated already in the PCA, namely the length of outer petals and the number of stigma rays (Tab. 5). Leaf length and maximum leaf width also had some, though less, discrimination power (Tab. 5). In the CDA, the chi-square test for all canonical roots for the data matrix confirmed their statistical significance. Standardized coefficients of the discriminant function for canonical variables are presented in Tab. 5 . The scatterplot of the canonical variables shows three distinct, though slightly overlapping, groups formed by the taxa (Fig. 6). The first canonical discriminant function clearly separates N. tetragona from N. alba and N. candida.

Tab. 5 Values of Wilks' lambda, partial Wilks' lambda and $P$ values for the four quantitative characters provided by discriminant analysis of individual plants.

\begin{tabular}{lccccc} 
Character & $\begin{array}{c}\text { Wilks' } \\
\text { lambda }\end{array}$ & $\begin{array}{c}\text { partial Wilks' } \\
\text { lambda }\end{array}$ & P value & Root 1 & Root 2 \\
\hline LoOP & 0.54 & 0.732 & 0.0000 & -0.71 & $\mathbf{0 . 8 1}$ \\
LL & 0.39 & 0.998 & 0.7033 & & \\
MLW & 0.39 & 0.998 & 0.6985 & & \\
NoSR & 0.46 & 0.862 & 0.0000 & -0.50 & $\mathbf{- 0 . 9 5}$ \\
Eigenvalue & - & - & - & 1.51 & 0.01 \\
Cumulative & - & - & - & 0.99 & 1.00 \\
proportion & & & & & \\
\hline
\end{tabular}

Standardized coefficients for canonical variables (roots 1 and 2) are also shown. Values for which discriminant functions are most weighted are given in bold. See Tab. 2 for character abbreviations.

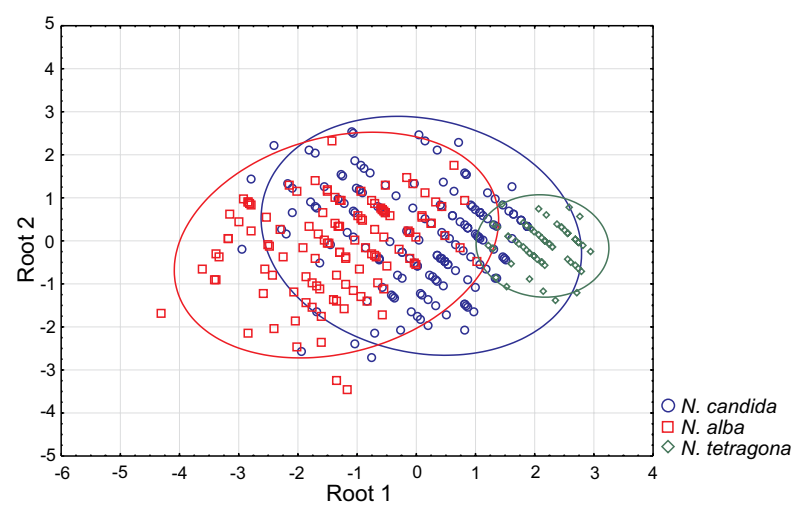

Fig. 6 Scatterplot presenting the results of canonical discriminant analysis of specimens representing the three investigated Nymphaea species delimited based on distinct genome sizes.

A principal coordinate analysis ( $\mathrm{PCoA}$ ) scatterplot using both qualitative and quantitative characters did not clearly separate the groups of individuals representing particular taxa (Fig. 7). Individuals representing $N$. tetragona formed the most distinct group. In contrast, specimens of $N$. candida and N. alba overlapped to a great extent. Nevertheless, the recognized taxonomic groups are better separated as compared to PCA and DA scatterplots (Fig. 3, Fig. 6), which proves the usefulness of qualitative characteristics for taxonomic decision-making. Nymphaea $\times$ borealis merges with the N. alba group.

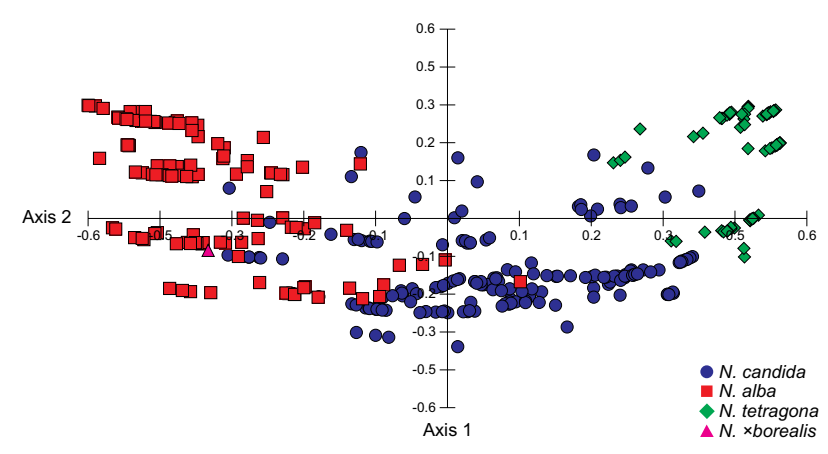

Fig. 7 Scatterplot presenting the result of principal coordinate analysis (PCoA) of specimens representing Nymphaea candida, $N$. alba, N. tetragona and $N$. $\times$ borealis delimited based on distinct genome sizes.

\section{Determination key for investigated Eurasian Nymphaea species}

1 Filaments of inner stamens linear. Central stigma projection short and hemispherical ............ alba L.

$1^{\star}$ Filaments of inner stamens lanceolate or round. Central stigma projection long and conical ..................2

2 Stigma yellow to red. Cup base tetrahedral without a rib. Number of stigma rays (7-)8-15(-20). Length of outer petals (26-)30-66(-82) mm. Maximum leaf width (77-)118-265(-345) mm............ candida C. Presl

$2^{*}$ Stigma red. Cup base tetrahedral with a rib. Number of stigma rays (6-)7-10(-11). Length of outer petals (11-)16-30(-35) mm. Maximum leaf width (42-)69152(-190) $\mathrm{mm}$.....

N. tetragona Georgi

\section{Discussion}

Many authors have reported that N. alba, N. candida, $N$. tetragona and $N$. $\times$ borealis can be distinguished by quantitative characters, such as length of outer petals, maximum leaf width and leaf length $[10,13,19,20,26]$. Additionally, the number of stigma rays has been recognized as one of the most important diagnostic characters in the majority of published studies $[9,10,13,14,16,19,20,24,26,31]$. Our morphometric results confirmed the taxonomic value of the following characters: length of outer petals, maximum leaf width and number of stigma rays. All these traits, however, can vary considerably what is evidenced by classifying method of discriminant analysis (Tab. 6), where partial incongruence between molecular and morphological taxa identification was revealed. Distinguishing of N. alba and $N$. candida is particularly challenging and hardly possible solely based on quantitative characters.

Although leaf length was previously regarded as taxonomically important, our results did not confirm its diagnostic 
Tab. 6 Results of classificatory discriminant analysis.

\begin{tabular}{llll}
\hline & \multicolumn{3}{c}{$\begin{array}{r}\text { Classification matrix of specimens (number/\% of } \\
\text { specimens classified into each group) }\end{array}$} \\
\cline { 2 - 4 } Taxon & N. candida & N. alba & N. tetragona \\
\hline N. candida & $125 / 75.76$ & $31 / 18.79$ & $9 / 5.45$ \\
N. alba & $42 / 35.59$ & $76 / 64.41$ & $0 / 0$ \\
N. tetragona & $9 / 13.24$ & $0 / 0$ & $59 / 86.76$ \\
\hline
\end{tabular}

The matrix classification of specimens based on morphological data into particular taxonomic groups delimited by unique genome size (number of individuals and percentage). Rows - observed classification; columns - predicted classification.

value in the species determination. Qualitative traits examined by us that proved to be helpful in identification are (Fig. 5): shape of inner stamen filament, shape of central stigma projection, color of stigma and shape of cup base. The last character however is more variable that previously assumed [13,17,19,24,26,27,31]. Except typical and round cup bases we recorded also the tetrahedral ones within $N$. alba individuals (Fig. 5). The variation of cup bases was also noticed by Kabátová et al. [20], indicating that this character should be used with caution as well. The taxonomic value of the shape of the first main leaf vein turned out to be quite low. According to Kabátová et al. [20] this trait is useful for identification of N. alba and N. candida, however it cannot distinguish $N$. tetragona, which has the same shape of the first main leaf vein as N. alba.

Our study revealed a higher morphological variation of individuals of N. alba, N. candida and N. tetragona than reported in the literature. The values of particular traits obtained in this study are similar to those published previously $[9,10,13,14,16,19,20,24,26,31]$, however, their ranges are wider (see Tab. 4, Fig. 5). In all examined species, individuals with narrower and wider leaves were recorded, as well as those with shorter and longer outer petals. Considerable phenotypic variation of quantitative traits was confirmed by classificatory discriminant analysis (Tab. 6).

In general, N. alba has the greatest size of both vegetative and generative parts, including the leaf length and width, length of outer petals and the number of stigma rays. In contrast, $N$. tetragona has the smallest size of above mentioned parts and the lowest number of stigma rays (Tab. 4). The plant size, however, should be taken with caution, because

\section{Acknowledgments}

Our sincere thanks are due to H. Ciecierska, J. Ruszczyńska, P. Dynowski, E. Kluczenko, S. Kluczenko, G. Larsson, J.A. Dragon, M. Kozhin, R.A. Murtozaliev and the International Waterlily and Water Gardening Society (in particular C.B. Hellquist) for providing some material. Some sampling were performed in the Russian nature reserves "Kostomukshskij" (special thanks to S.V. Tarkhov), "Astrakhanskij” (special thanks to A.K. Gorbunov), "Il'menskij" (special thanks to E.I. Vejsberg), "Khinganskij” (special thanks to S.G. Kudrin), "Dal'nevostochnyj Morskoj" (special thanks to A.N. Malyutin), in the national park "Kondinskije Ozjora" (special thanks to A.L. Vasina), in the nature-historical reserve "Arkaim" (special thanks to E. Chibiljov), and at the biological station "Lake Moldino" of Moscow growing conditions may strongly influence the morphological appearance of Nymphaea individuals $[29,42,43]$. This was also observed in our study: individuals of Nymphaea alba from the humic lake (population No. 103) were visibly smaller and resembled N. candida. The opposite situation was also noticed: individuals of $N$. candida occurring in eutrophic lakes (populations No. 104, 105, 109) developed larger leaves and flowers than are usually recorded for this species. Under such conditions proper identification was only possible based on qualitative morphological traits.

All qualitative and quantitative characters of hybridogenous $N$. candida [8] are intermediate between its parental species N. alba and N. tetragona (Tab. 4, Fig. 5). Qualitative traits shared by N. candida and N. tetragona include: red- or orange-colored stigma and a long conically-shaped stigma projection. The shape of the inner stamen filament and the shape of cup base are the only investigated qualitative traits that differentiate N. candida from N. tetragona. Oval-shaped inner stamens and tetrahedrally-shaped cup base with a rib are diagnostic for $N$. tetragona (Fig. 5).

The sole hybrid individual of $N$. $\times$ borealis detected during this study combined morphological traits of both parental species, what is congruent with previous observations $[13,20,26,27]$. The shape of inner stamen filaments and the cup base shape were typical for N. candida, while the shape of central stigma projection resembled N. alba. Quantitative traits were intermediate between the values typical for the parental species except for the maximum leaf width, which exceeded even that of N. alba $(353 \mathrm{~mm})$.

Phenotypic similarities between N. alba, N. candida and $N$. tetragona [8] seems to favor hybridization. Ejankowski and Małysz [24] state that due to the absence of barriers preventing crossing in Nymphaea, hybrids may in time become more widespread than parental species. This hypothesis, however, was not confirmed by Kabátová et al. [20], who, based on genome size investigations, found that $N$. $\times$ borealis occurred definitely much less frequently than previously assumed and only 11 of 625 specimens from the Czech Republic examined by these authors were of hybrid origin. Our results also show that the hybrid is not as frequent as previously thought. Although based on morphological data, hybrid origin was suspected in $32.3 \%$ of investigated specimens (see Tab. 1), all of them turned out to be N. alba or N. candida based on the genome size values. Only one cytometrically-proven $N$. $\times$ borealis individual was revealed among 353 specimens investigated. Therefore, it can be concluded that morphologically intermediate forms are largely a result of phenotypic plasticity rather than products of interspecific hybridization.

South-West High School. We are also indebted to K. Dvořáková and J. Krejčíková for their help with flow cytometric measurements and two anonymous reviewers for their valuable comments on an earlier version of the manuscript. The study was partly financially supported by project No. 528-0203-0881 from the University of Warmia and Mazury in Olsztyn to M.D. Flow cytometric analyses were supported by the Czech Science Foundation (project 14-36079G, Centre of Excellence PLADIAS).

\section{Authors' contributions}

The following declarations about authors' contributions to the research have been made: idea of study, research design: MD, JZG, PV; biometric 
measurements and scoring the data: MD, PV; flow cytometry analysis: JS; statistical analyses: $\mathrm{KR}, \mathrm{MD}$; interpretation of the results, writing the manuscript: MD, KR, JS, JZG.

\section{Competing interests}

The following declarations about authors' competing interests have been made: JZG: as an editor of the Acta Societatis Botanicorum Poloniae journal I declare that I had no competing interests during assessment of the manuscript; other authors: no competing interests.

\section{References}

1. Borsch T, Hilu KW, Wiersema JH, Löhne C, Barthlott W, Wilde V. Phylogeny of Nymphaea (Nymphaeaceae): evidence from substitutions and microstructural changes in the chloroplast trnT-trnF region. Int J Plant Sci. 2007;168(5):639-671. http://dx.doi.org/10.1086/513476

2. Gupta PP. Cytogenetics of aquatic ornamentals. VI. Evolutionary trends and relationships in the genus Nymphaea. Cytologia. 1980;45:307-314. http://dx.doi.org/10.1508/cytologia.45.307

3. Borsch T, Löhne C, Mbaye MS, Wiersema J. Towards a complete species tree of Nymphaea: shedding further light on subg. Brachyceras and its relationships to the Australian water-lilies. Telopea. 2011;13(1-2):193-217.

4. Hultén E, Fries M. Atlas of North European vascular plants. North of the tropic of cancer. Vol. I. Königstein: Koeltz Scientific Books, Federal Republic of Germany; 1986.

5. Komarov VL. Nymphaea L. In: Komarov VL, editor. Flora of the USSR. Jeruzalem: Israel Program for Scientific 19 Translators; 1970. p. 8-12. (vol 7).

6. Tutin TG, Webb DA. Nymphaea. In: Tutin TG, Burges NA, Chater AO, Edmondson JR, Heywood VH, Moore DM, et al., editors. Flora Europaea I. 2nd ed. Cambridge: Cambridge University Press; 1993. p. $246-247$.

7. Zając M, Zając A. The geographical elements of native flora of Poland. Kraków: Drukarnia Uniwersytetu Jagiellońskiego; 2009.

8. Volkova PA, Trávníček P, Brochmann C. Evolutionary dynamics across discontinuous freshwater systems: Rapid expansions and repeated allopolyploid origins in the Palearctic white water-lilies (Nymphaea). Taxon. 2010;59:483-494.

9. Rothmaler W. Exkursionsflora. Kritischer Band. Berlin: Volk und Wissen Volkseigener Verlag Berlin; 1976.

10. Tomšovic P. Nymphaeaceae. In: Hejný S, Slavík B, editors. Květena České socialistické republiky. Praha: Academia; 1988. p. 355-359.

11. Szańkowski M, Kłosowski S. Habitat conditions of nymphaeid associations in Poland. Hydrobiologia. 1999;415:177-185. http://dx.doi. org/10.1007/978-94-017-0922-4_25

12. Gąbka M. Habitat requirements of nymphaeids in humic lakes of the Wielkopolska region (western Poland). Biodivers Res Conserv. 2006;3-4:357-360.

13. Neuhäusl R, Tomšovic P. Rod Nymphaea (L.) Smith v Čechoslovensku. Preslia. 1957;29:225-249.

14. Jasiewicz A. Flora Polski. Rośliny naczyniowe. Warszawa: Państwowe Wydawnictwo Naukowe; 1985. (vol 4).

15. Szafer W, Kulczyński S, Pawłowski B. Rośliny polskie. Część I. Warszawa: Państwowe Wydawnictwo Naukowe; 1988.

16. Kubát K. Klíč ke květně České republiky. Praha: Academia; 2002.

17. Rutkowski L. Klucz do oznaczania roślin naczyniowych Polski niżowej. Warszawa: Wydawnictwo Naukowe PWN; 1998.

18. Werner K, Hellwig F. Hybridization between Nymphaea alba and Nymphaea candida investigated by AFLP fingerprinting and morphological data. In: Abstracts of 17th symposium "Biodiversity and evolutionary biology". Bonn; 2006. p. 227.

19. Volkova PA, Shipunov AB. Morphological variation of Nymphaea (Nymphaeaceae) in European Russia. Nord J Bot. 2007;25:329-338. http://dx.doi.org/10.1111/j.0107-055X.2007.00140.x

20. Kabátová K, Vít P, Suda J. Species boundaries and hybridization in
central-European Nymphaea species inferred from genome size and morphometric data. Preslia. 2014;86:131-154.

21. Caspary R. Neue und seltene Pflanzen Preussens, gefunden 1870. Schriften der Köniüichen Physikalisch-Ökonomischen Gesellschaft zu Königsberg. 1871:61-64.

22. Camus EG. Statistique ou catalogue des plantes hybrids spontanées de la flore européenne. Journal de Botanique. 1898;12:97-103.

23. Gąbka M, Owsianny PM, Sobczyński T. Acid lakes in the Wielkopolska region - physic-chemical properties of water, bottom sediments and the aquatic micro- and macrovegetation. Limnological Review. 2004;4:81-88.

24. Ejankowski W, Małysz B. Morphological variability of the water lily (Nymphaea) in the Polesie Zachodnie region, Eastern Poland. Biologia. 2011;66(4):604-609. http://dx.doi.org/10.2478/s11756-011-0055-9

25. Ciecierska H. Makrofity jako wskaźniki stanu ekologicznego jezior. Rozprawy i monografie. Olsztyn: Wydawnictwo Uniwersytetu Warmińsko-Mazurskiego; 2008.

26. Muntendam JB, Povel GDE, van der Velde G. Morphometric patterns in the Nymphaea alba-candida complex. Acta Botanica Neerlandica. 1996;45(3):279-302. http://dx.doi.org/10.1111/j.1438-8677.1996. tb00517.x

27. Nowak A, Nowak S. The problem of the occurrence of Nymphaea candida C. Presl in the Opole Silesia. Nat J (Opole). 2007;40:25-33.

28. Conrad HS. The waterlilies: a monograph of the genus Nymphaea. Washington, DC: Carnegie Institution of Washington; 1905. http:// dx.doi.org/10.5962/bhl.title.23557

29. Heslop-Harrison Y. Nymphaea L. em. Sm. (nom. conserv.). J Ecol. 1955;43:719-734. http://dx.doi.org/10.2307/2257032

30. Les DH, Philbrick CT. Studies of hybridization and chromosome number variation in aquatic plants: evolutionary implications. Aquat Bot. 1993;44:181-228. http://dx.doi.org/10.1016/0304-3770(93)90071-4

31. Wayda M. The distribution of Nymphaea candida C. Presl (Nymphaeaceae) in Poland. Acta Soc Bot Pol. 2000;69(1):75-79. http://dx.doi. org/10.5586/asbp.2000.009

32. Nowak A, Nobis M, Dajdok Z, Zalewska-Gałosz J, Nowak S, Nobis A, et al. Revision of Nymphaea candida range - new data on the distribution and habitat preferences of the species in southern Poland. Acta Soc Bot Pol. 2010;79(4):333-350. http://dx.doi.org/10.5586/asbp.2010.041

33. Otto F. DAPI staining of fixed cells for high-resolution flow cytometry of nuclear DNA. In: Crissman HA, Darzynkiewicz Z, editors. Methods in cell biology. New York, NY: Academic Press; 1990. p: 105-110. (vol 33). http://dx.doi.org/10.1016/S0091-679X(08)60516-6

34. Suda J, Trávníček P. Reliable DNA ploidy determination in dehydrated tissues of vascular plants by DAPI flow cytometry: new prospects for plant research. Cytometry A. 2006;69A(4):273-280. http://dx.doi. org/10.1002/cyto.a.20253

35. Doležel J, Sgorbati S, Lucretti S. Comparison of three DNA fluorochromes for flow cytometric estimation of nuclear DNA content in plants. J Plant Physiol. 1992;85:625-631. http://dx.doi. org/10.1111/j.1399-3054.1992.tb04764.x

36. Sokal RR, Sneath PH. Principles of numerical taxonomy. San Francisco, CA: W.H. Freeman; 1963.

37. Sneath PH, Sokal RR. Numerical taxonomy. San Francisco, CA: W.H. Freeman; 1973.

38. Cattell RB. The scree test for the number of factors. Multivariate Behav Res. 1966;1:245-276. http://dx.doi.org/10.1207/s15327906mbr0102_10

39. Gower JC. A general coefficient of similarity and some of its properties. Biometrics. 1971;27:857-874. http://dx.doi.org/10.2307/2528823

40. Marhold K. Multivariate morphometrics and its application to monography at specific and infraspecific levels. In: Stuessy TF, Lack HW, editors. Monographic plant systematics: fundamental assessment of plant biodiversity. Ruggell: Gantner; 2011. p. 73-99.

41. Kovach WL. MVSP - A Multivariate Statistical Package for Windows, ver. 3.1. Pentraeth: Kovach Computing Services; 1999.

42. Glück H. Biologische und morphologische Untersuchungen über 
Wasser-und Sumpfgewächse. Vierter Teil: Untergetauchte und Schwimmblattflora. Jena: G. Fischer; 1924.

43. Nierbauer KU, Kanz B, Zizka G. The widespread naturalisation of
Nymphaea hybrids is masking the decline of wild-type Nymphaea alba in Hesse, Germany. Flora. 2014;209(2):122-130. http://dx.doi. org/10.1016/j.flora.2013.12.005 